\title{
Enzymatic Assay of Urinary Formic Acid as an Index of Methanol Exposure
}

Key words : Formic acid-Methanol-Formic acid dehydrogenase-Enzymatic assay-Biological monitoring

Methanol has been widely used as an ingredient in thinner and for the extraction of biological materials. When methanol is inhaled, it is converted into formaldehyde by alcohol dehydrogenase and into formic acid by aldehyde dehydrogenase. The formic acid thus produced is excreted into urine ${ }^{1)}$ as a major metabolite of methanol. In the urine of workers exposed to methanol, the concentration of formic acid is higher than that of methanol. ${ }^{2)}$ A gas-liquid chromatographic method has been used for the determination of urinary methanol and formic acid. ${ }^{3)}$ In this gas chromatographic assay, formic acid is converted into $\mathrm{N}, \mathrm{N}$-dimethylformamide by a 2-step reaction and measured by gas chromatography with $\mathrm{TCD}^{4)}$ or a thermoionic $\mathrm{N}$-detector. ${ }^{5)}$ These procedures are complicated and time-consuming. On the other hand, Grady et al. ${ }^{6}$ described a method for the determination of blood formic acid using formic acid dehydrogenase, while Ohmori et al. compared the results obtained by the enzymatic method and their HPLC method on biological specimens.

The present report describes a simple and specific enzymatic method of formic acid analysis of urine samples from workers exposed to methanol.

Urine specimens were collected from 5 workers producing solid alcoholic fuel and exposed to about 120ppm of methanol by the end of their shift. All reagents used were of analytical grade and purchased from Wako Pure Chemicals Ltd. (Osaka, Japan). Formate dehydrogenase (FDH; 0.50units/mg solid), NADdiaphorase (NAD 6g/1; diaphorase, 500units/1) and p-iodonitrotetrazolium violet (INT) were purchased from Sigma Co. (Ill, U. S. A.). Phosphate buffer (100 mmol/1, pH 6.0) was prepared by mixing $100 \mathrm{mmol} / 1 \mathrm{KH}_{2} \mathrm{PO}_{4}$ and $100 \mathrm{mmol} / 1$ $\mathrm{Na}_{2} \mathrm{HPO}_{4}(5: 1)$. NAD-diaphorase was dissolved into the phosphate buffer to yield a concentration of $1.8 \mathrm{mg} / \mathrm{ml}$. Buffered NAD-diaphorase-INT was prepared by adding $40 \mathrm{ml}$ of INT to $20 \mathrm{ml}$ of buffered NAD-diaphorase.

One hundred $\mu 1$ urine samples were mixed by a Vortex mixer $(5 \mathrm{sec})$ with 100 $\mu 1$ acetonitorile in $10 \mathrm{ml}$ test tubes and centrifuged $(1,600 \mathrm{~g})$ for $10 \mathrm{~min}$. The supernatants $(100 \mu \mathrm{l})$ were added to $10 \mathrm{ml}$ test tubes containing $2.5 \mathrm{ml}$ buffered NAD-diaphorase-INT. After mixing, $60 \mu \mathrm{l}$ of FDH (5units $/ \mathrm{ml} \mathrm{kept} \mathrm{at} 5^{\circ} \mathrm{C}$ ) was added, mixed and left at room temperature $\left(20^{\circ} \mathrm{C}\right)$ for $10 \mathrm{~min}$. Each reaction mixture was transferred into a glass cuvette of a double-beam spectrophotometer (Hitachi Model, 100-60). The zero adjustment of the instrument was made against water and the absorbancies of red were read at $500 \mathrm{~nm}$. The procedure 
used in this study was essentially the same as that described by Grady et al. ${ }^{6}$ except that the $3.0 \mathrm{ml}$ of buffered NAD-diaphorase-INT was replaced by $2.5 \mathrm{ml}$.

Packed column GC: Modification of the direct injection method for gas chromatography devised by Kawai et al. ${ }^{8}$ ) was used. Specimens of $0.5 \mathrm{ml}$ were transferred into test tubes and centrifuged at 3,000 rpm for 5 minutes. Each $1 \mu 1$ of the supernatant solution was analyzed for methanol by gas chromatography under the following instrumental conditions: gas chromatograph, Shimadzu GC7 AG (Shimadzu Seisakusho, Ltd., Kyoto); column, glass, $4 \mathrm{~m} \times 3 \mathrm{~mm}$ at the temperature level of $55^{\circ} \mathrm{C}$; packing, 10 percet SBS 100; support, Shimalite TPA (60-80mesh); carrier gas, $\mathrm{N}_{2} 45 \mathrm{ml} / \mathrm{min}$, air $0.5 \mathrm{~kg} / \mathrm{cm}^{2}$ and $\mathrm{H}_{2} 0.6 \mathrm{~kg} / \mathrm{cm}^{2}$; detector, FID; and injection temperature of $180^{\circ} \mathrm{C}$.

Different concentrations of formic acid ranging from 10 to $200 \mathrm{mg} / 1$ were prepared for drawing the calibration curve. An equal volume of water or urine was added to the each solution, and $O$. D. was recorded at $500 \mathrm{~nm}$ after enzymatic digestion. A linear relationship between the concentration of formic acid and the enzymatic reaction was established (Fig. 1).

Variation coefficients (SD/mean) for the values of formic acid in the same urine specimens containing 50 and $100 \mathrm{mg} / 1(\mathrm{n}=5$ for each) were 4.22 and 3.19

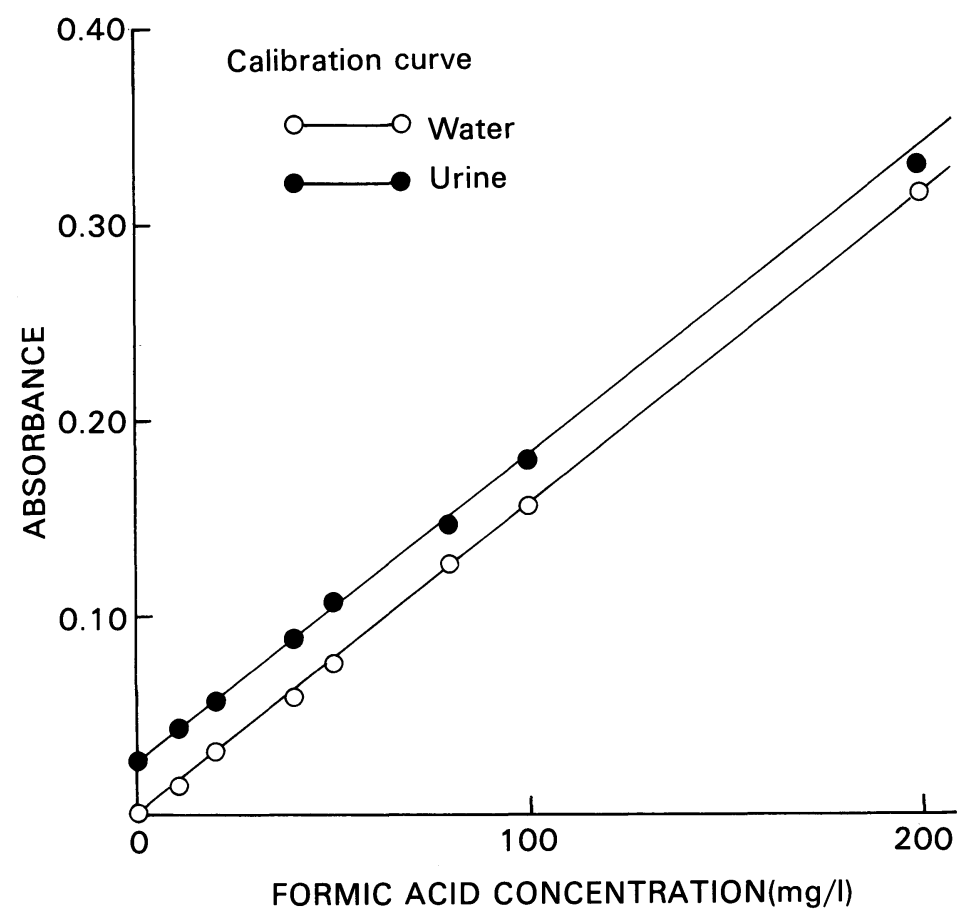

Fig. 1. Calibration curve for formic acid added to water and urine. 


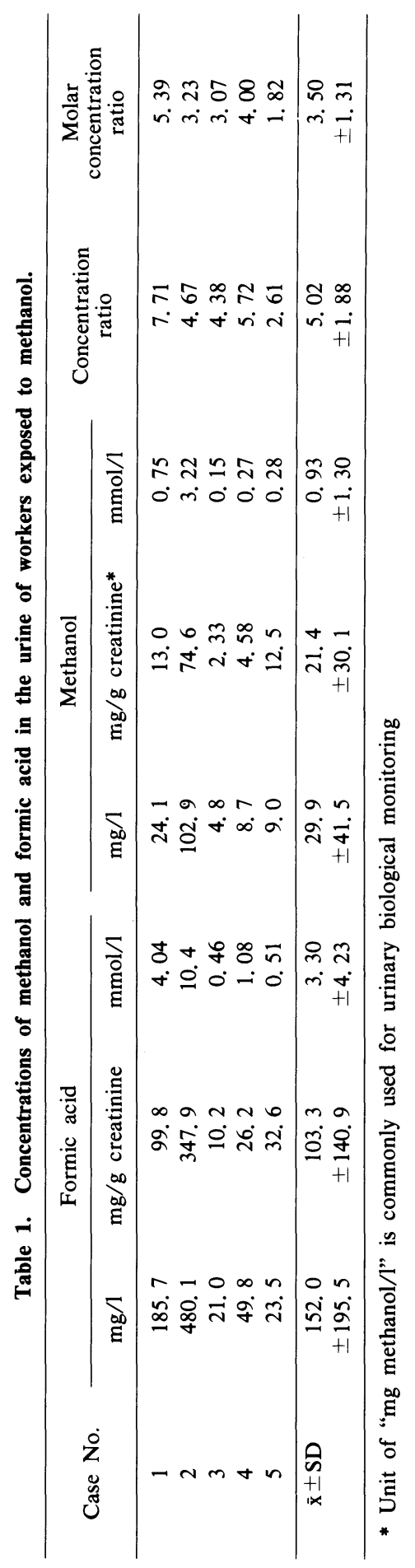


percent, respectively.

Samples of formic acid at concentrations of 10, 20, 40, 80 and $400 \mathrm{mg} / 1$ were added to equal volumes of normal urine from unexposed subjects and the recovery rates (mean $\pm S D$ ) were determined by enzymatic assay as 104.4 \pm 7.68 , $96.9 \pm 9.40,97.3 \pm 10.3,93.9 \pm 5.45$ and $96.2 \pm 1.68$ percent, respectively.

Urine samples from 29 male controls between 30 and 39 years of age and without occupational exposure to methanol and formic acid were studied by enzymatic assay. After correction for urinary creatinine, the formic acid and methanol content of unexposed urine revealed a log-normal distribution. The geometric mean $(\mathrm{m})$ of urinary formic acid was $7.36 \mathrm{mg} / \mathrm{g}$ creatinine, the geometric standard deviation (SD) was 1.89 and the upper 95 percent fiducial limit of formic acid was $21.3 \mathrm{mg} / \mathrm{g}$ creatinine $(\mathrm{n}=29)$. The geometric mean $(\mathrm{m})$ of urinary methanol measured by gas chromatography on acetonitrile extract was $1.40 \mathrm{mg} / 1$ or $1.16 \mathrm{mg} / \mathrm{g}$ creatinine, the geometric standard deviation (SD) was 1.77 or 2.19 , and the upper 95 percent fiducial limit of methanol was $3.58 \mathrm{mg} / 1$ or $4.22 \mathrm{mg} / \mathrm{g}$ creatinine $(\mathrm{n}=29)$. Urinary formic acid in unexposed subjects is reported to average $15.1 \mathrm{mg} / \mathrm{g}$ creatinine ${ }^{3)}, 12.7 \mathrm{mg} / \mathrm{1}^{2)}$ and $11.9 \mathrm{mg} / \mathrm{l}^{9}$, higher than the $7.36 \mathrm{mg} / \mathrm{g}$ creatinine in the present experiment. The concentration of urinary methanol in unexposed subjects is reported to be $0.73 \mathrm{mg} / \mathrm{1}^{10)}, 1.1 \mathrm{mg} / \mathrm{l}^{2)}$ and 2.05 $\mathrm{mg} / \mathrm{l}^{8)}$ on average. The normal level of methanol in the present study was $1.4 \mathrm{mg}$ / 1 , in agreement with previous reports.

The detection limit of a compound was $5 \mathrm{mg} / \mathrm{l}$ which was taken as the amount of absorbance five times that of the background.

The concentrations of methanol and formic acid in the urine of workers exposed to methanol were determined. Results are shown in Table 1. The mean concentration ratio and molar concentration ratio $(\mathrm{m} \pm \mathrm{SD})$ of formic acid to methanol in urine were $5.02 \pm 1.88$ and $3.50 \pm 1.31$ respectively, indicating that the concentration of formic acid excreted in urine was higher than that of methanol.

Gas chromatographic and enzymatic assay methods have been reported for the determination of formic acid in biological specimens. In the gas chromatographic method, boron trifluoride-methanol used as a reagent for the methylation of formic acid is highly irritating to the eyes and other mucous membranes. Moreover, the separation of methylformic acid and methanol by the gas chromatographic procedure is not complete. ${ }^{5)}$ The enzymatic method is specific for formic acids and the method has a higher analytical sensitivity and requires less time for analysis than gas chromatography.

In conclusion, the enzymatic method of urinary formic acid analysis used in this study is recommended for urinary biological monitoring of workers exposed to methanol as an index of methanol exposure. 


\section{ACKNOWLEDGMENT}

We will express our thanks to Prof. Shinji Ohmori and Dr. Toyohiro Taguchi for their guidance of this work and Prof. Kazuhisa Taketa for reviewing the manuscripts.

\section{REFERENCES}

1) Leisivuori J. Biological monitoring and toxicological aspects of formic acid and methanol. Kuopion Yliopiston Julkaisuja publications of the University of Kuopio, Helsinki 1988; 1-53.

2) Heinrich $R$ and Angerer J. Occupational chronic exposure to organic solvents (X, Biological monitoring parameters for methanol exposure). Int Arch Occup Environ Health 1982; 50: 3419.

3) Liesivuori $J$ and Savolainen $H$. Urinary formic acid as an indicator of occupational exposure to formic acid and methanol. Am Ind Assoc J 1987; 48 (1): 32-4.

4) Bricknell K S and Finegold S M. Improved method for assay of formic acid by gas-liquid chromatography. J Chromatogr 1978; 151: 374-8.

5) Kimmerle $\mathrm{G}$ and Eben A. Metabolism studies of N, N-dimethylformamide. Int Arch Arbeitsmed $1975 ; 34: 127-36$.

6) Grady S and Osterloh J. Improved enzymatic assay for serum formate with colorimetric endpoint. J Anal Toxicol 1986; 10: 1-5.

7) Ohmori S, Sumii I, Toyonaga $Y$, Nakata $K$ and Kawase $M$. High-performance liquid chromatographic determination of formate as benzimidazole in biological samples. J Chromatogr 1988; 426: $15-24$.

8) Kawai T, Hirashima $J$ and Horiguchi S. Determination of urinary methyl alcohol by chromatography. J Science of Labour 1987; 63: 21-4.

9) Baumann K and Angerer J. Occupational chronic exposure to organic solvents VI. Formic acid concentration in blood and urine as an indicator of methanol exposure. Int Arch Occup Environ Health 1979; 42: 241-9.

10) Sedivec V, Mraz M and Flek J. Biological monitoring of persons exposed to methanol vapours. Int Arch Occup Environ Health 1981; 48: 257-71.

1) Department of Public Health, Okayama University

Masana Ogata', Medical School,

2-5-1 Shikata-cho, Okayama City, Okayama, 700, Japan

Tomoko Iwamoto" and

Kinki Occupational Health Service Center,

Toshio Kawai ${ }^{2)}$

2-3-8 Tosabori, Nishi-ku, Osaka, 550, Japan

(Received March 20, 1989 and in revised form May 22, 1989) 